\title{
COVID-19 lockdown: animal life, ecosystem and atmospheric environment
}

\author{
Harekrishna Bar ${ }^{1}$
}

Received: 27 May 2020 / Accepted: 22 September 2020 / Published online: 1 October 2020

(c) Springer Nature B.V. 2020

\begin{abstract}
The outbreak of COVID-19 leads to emergence of the global pandemic, but there is no specific vaccine recommended for COVID-19. More than 216 countries are struggling against the transmission of the disease, recovery and motility. Till date more than 0.948 million deaths out of 30.369 million confirmed cases are reported by WHO. Most of the nations adopted partial or complete 'lockdown' and imposed 'social distancing' to control the rapid transmission of COVID-19 and its consequence. Though global economic growth declined due to nationwide lockdown, there are certain positive impacts on environment. This review article has discussed the effects of nationwide lockdown aiming to community transmission COVID-19 on animal life behaviour and atmospheric environment in different aspects. In the lockdown period, the levels of $\mathrm{NO}_{2}$ and carbon emission remarkably decrease in atmosphere due to restricted consumption of fossil fuel by industries, thermal power stations and air transportations. The concentration of $\mathrm{NO}_{2}$ dropped by $45-54 \%$ in the atmosphere of most populated cities in Europe. The intensities of particulate matters $\mathrm{PM}_{2.5}$ and $\mathrm{PM}_{10}$ decreased by $43 \%$ and $31 \%$ respectively, at lower atmosphere indicating improvement in air qualities in different parts of world caused by less traffic and construction activities. SPM reduced up to $15.9 \%$, showing improvement in surface water quality. New deserted bank has developed due to less river activities in this period. Noise pollution remarkably dropped below $60 \mathrm{db}$ even in crowded cities. Thus, the atmospheric environment has resumed some extent in all respect by means of such global-wide lockdown aiming to control COVID-19 pandemic. The behavioural changes of wild animals, birds, butterfly, pets and street animals that reflected on ecosystem of their relative region indicate the non-interference of human activities on lives of natural creatures during lockdown period. There is certain correlation between atmospheric change with the behavioural changes of natural creature during lockdown period. The objective of this study is to focus the critical analysis of the effect of human activities on atmospheric environment for sustainable ecosystem in long term. Significantly, there is ample scope of research on sustainable development of atmospheric environment and ecosystem of creature in absence of human being.
\end{abstract}

Harekrishna Bar

bar.krishna1981@gmail.com

Extended author information available on the last page of the article 
Keywords COVID-19 - Lockdown - Atmospheric environment · Wildlife - Aquatic life · Ecosystem

$\begin{array}{ll}\text { Abbreviations } & \\ \text { COVID-19 } & \text { Coronavirus disease 2019 } \\ \text { SARS-CoV } & \text { Severe acute respiratory syndrome coronavirus } \\ \text { MERS-CoV } & \text { Middle East respiratory syndrome coronavirus } \\ \text { SARS-CoV 19 } & \text { Severe acute respiratory syndrome coronavirus 2019 } \\ \text { HCoV-229E } & \text { Human coronavirus 229E } \\ \text { HCoV-OC43 } & \text { Human coronavirus OC43 } \\ \text { HCoV-NL63 } & \text { Human coronaviruses NL63 } \\ \text { HCoV-HKUI } & \text { Human coronavirus HKUI } \\ \text { bat-SL-Cov-ZC45 } & \text { Bat SARS-like coronavirus ZC 45 ( Zhoushan, China) } \\ \text { bat-SL-Cov-ZC21 } & \text { Bat SARS-like coronavirus ZC 21 (Zhoushan, China) } \\ \text { ACE2 } & \text { Angiotensin converting enzyme 2 } \\ \text { RBD } & \text { Receptor binding domain } \\ \text { RBM } & \text { Receptor binding motif } \\ \text { PM } & \text { Particulate matter } \\ \text { BC } & \text { Black carbon } \\ \text { ASF } & \text { African swine fever } \\ \text { ESA } & \text { European space agency } \\ \text { RNA } & \text { Ribonucleic acid } \\ \text { DNA } & \text { Deoxyribonucleic acid } \\ \text { ORF } & \text { Open reading frame } \\ \text { RTC } & \text { Replicase-transcriptase complex } \\ \text { ER } & \text { Endoplasmic reticulum } \\ \text { ERGIC } & \text { Endoplasmic reticulum-Golgi intermediate compartment } \\ \text { RT-PCR } & \text { Reverse transcription polymerase chain reaction } \\ \text { RdRp } & \text { RNA-dependent RNA polymerase } \\ \text { SPM } & \text { Suspended particulate matter } \\ \text { NGO } & \text { Non-governmental organization } \\ \text { WHO } & \text { World health organization } \\ & \end{array}$

\section{Introduction}

Outbreak of COVID-19, the biggest pandemic in world (Lu et al. 2020) is likely to be spread from Huanan Seafood Market, Wuhan, Hubei Province, China. Rolling data toll with 30,369,778 confirmed cases, from which 948,795 have died. Corona viruses belong in large family including four genera- $\alpha, \beta, \gamma$ and $\delta$ viruses; but all strains are not virulent. Among these three strains like SARS-CoV, MERS-CoV and SARS-CoV 19 found to be more deadly than the others like HCoV-229E, HCoV-OC43, HCoV-NL63 and HCoVHKUI (Mackay and Arden 2015). Interestingly, the strain CoV-19 or SARS-CoV 19 is found closely related to two bat-derived SARS-like coronavirus namely bat-SL-Cov-ZC45 and bat-SL-Cov-ZXC21 which were isolated in 2018 from Zhoushan, China. Genomic analysis on Cov-19 has established the $79 \%$ genetic similarity with SARS creating CoV (SARS-CoV) and 50\% similarity with MERS creating CoV (MERS-CoV), confirming that $\mathrm{CoV}-19$ is mutated from the above two. So there is debate on the origin of new CoV-19 is 
the man made mutated or naturally mutated strain of corona virus (Andersen et al. 2020; Science News 2020).

Corona viruses are single-stranded RNA with a genome comprising 29,891 nucleotides with helical symmetrical enveloped and outside diameter ranging from 80-120 nm (Lu and Liu 2012; Lai et al. 2007). The genomic study of human corona virus encodes four structural protein including spike (S), envelop (E), membrane $(\mathrm{M})$ and nucleocapid $(\mathrm{N})$ along with 16 nonstructural (np1-16) and 5 to 8 accessory protein (Jiang et al. 2020). The spikes on outer surface are suitable to attach with living cells. The spike S protein comprises with two functional subunits, S1 and S2; where S1 subunit facilitates the attachment of the virus at the surface of the cell and S2 subunit undergoes membrane fusion. The spike proteins at surface have a functional furan-based multi-basic cleavage site at the S1-S2 boundary through the incorporation of 12 nucleotides which led to the prediction achievement of three O-linked glycans around the site. The structural study revealed that the chemical structure of attacking site appears to fit for binding to the human receptor Angiotensin Converting Enzyme 2 (ACE2) (Yu et al. 2019). The receptor binding domain (RBD) of the $\mathrm{S} 1$ protein consists of five anti-parallel $\beta$ strands connecting with $\alpha$-helical and loop motifs and forming receptor binding motif (RBM), which attaches to ACE2 through N-terminal helix (Lan et al. 2020). Afterwards, it binds with S2 to form an anti-parallel six-helix bundle that accelerates the fusion of viral and cellular membrane, resulting viral genome enters into cytoplasm. The genomic RNA of SARS-CoV-2 starts multiplication through replicase gene encoding into two ORFs, repla and rep1b followed by formation of two polyproteins ppla and pplab. A replicase-transcriptase complex (RTC) is assembled from 16 unstructured proteins that creates suitable environment for RNA raplication and transcription into sub-genomic RNAs. Then viral structural proteins including S, E and M are translated attached with endoplasmic reticulum (ER) and processed for budding and assembly into endoplasmic reticulum-Golgi intermediate compartment (ERGIC). Finally, N protein encapsulates ERGIC into a membrane and formed a matured corona virus (Knoops et al. 2008; Fehr Perlman 2015; Huang et al. 2020). So after multiplication, it rapidly causes several blockage of lungs resulting respiratory obstruction and death of the patient.

Dry cough, fever, fatigue and difficulty in breathing are initial symptoms which is very likely to the common cough and cold in early stage. Later complications like pneumonia, kidney failure, acute respiratory problem etc. arise that lead the patient to death (Dong et al. 2020; Zhou et al. 2020). The mortality rate is comparatively high for older people, and the patient having pre-existing health problem like heart diseases, lung disease, asthma, diabetes cancer etc. and patient having low immunity power (Iswariya et al. 2019). Recently, dysfunction of smell and taste reported as clinical indicators of COVID-19 disease (Kerr et al. 2020). The recovery of infected persons depends upon the age, health conditions and clinical support. The viruses are spreading by sneezing, cough droplets and contact with a COVID-19 patient or even travel with infected area and enter the body through the mouth, nose and eyes. The virus can survive $2 \mathrm{~h}$ to few days in the aerosol droplets lying on the surface of the object. Mostly the infection may cause by touching those objects and then from own hands. So WHO recommended to wash hand frequently with soap or to clean with alcohol-based sanitizer. Some time no symptoms arise even after 14 days of infection, that time virus stay at incubation period in the human body. The asymptomatic transmitters unwillingly may spread the virus to the community through their normal activities. So the rapid and accurate detection of newly detected SARS Cov-2 virus among asymptomatic carriers and individual with mild symptom is the key factor to control the outbreak. Normally sputum, respiratory tract secretions, saliva from nose and throat including nasopharyngeal or oropharyngeal swabs specimens are analysed real-time reverse-transcription 
RT-PCR technique which is combination of the reverse transcription of RNA and amplification of cDNA region. Rapid diagnostic kits for COVID-19 bases on sequencing and microarray technique also approved for clinical use (Pang et al. 2020). Extraction of RNA followed by RT-PCR performed to amplify the RdRp, E and N genes of SARS Cov-2 is highly sensitive and specific for that particular strain giving the accurate result (Corman et al. 2020).

Till date there is no definite medicine or vaccine have been invented for treatment of COVID-19 due to rapid mutation in strain. Without complete clinical trial, the combination of hydroxychloroquine and azithromycin (Gautret et al. 2020) reported to have partial response. Other antiviral medicine like ribavirin, favipiravir, arbidol gaslidessivir (Agostini et al. 2018; Guangdi and Clercq 2020; Sheahan et al. 2020; Xu et al. 2020); to cilizumab and corticosteroids (Loutfy et al. 2003; Smith et al. 2020) are being examined. Besides these, peptide (EKI); 2 (ACE-2 based peptides (an angiotensin-converting enzyme), 3CLpro-1 (3CLpro inhibitor) and vinysulfone protease inhibitor; neuraminidase inhibitors, DNA synthesis inhibitors like tenofovir disoproxil and lamivudine are also attempt for COVID treatment (Liu et al. 2020). Remdesivir is reported satisfactory result against wide variety of $\mathrm{CoV}$, but use of this drug is still under investigation on this specific strain (Ko et al. 2020).

Many research groups working around the clock to find appropriate vaccine adopting different strategies including nucleotide-based (DNA vaccine and mRNA vaccine), subunit vaccine, recombinant vector vaccine, attenuated vaccine, inactivated virus vaccine. Few vaccine candidates of them are under clinical trial at different phases like NVX-CoV2373 (Novavax) (MD USA), a nanoparticle-based immunogenic vaccine; mRNA-1273, a novel lipid nanoparticle-encapsulated mRNA-based vaccine designed by Emory University, USA; INO-4800, DNA vaccine developed by Inovio Pharmaceuticals (PA, USA); LVSMENPDC developed by Shenzhen Geno-Immune Medical Institute, China etc. (Kaur and Gupta 2020) Out of them, ChAdOx1 nCoV-19 vaccine which is based on an adenoviral vaccine vector selected by University of Oxford, UK gets ahead of safety and immunogenicity phase-I and phase II clinical trial (Folegatti et al. 2020). The vector-based heterologous prime-boost COVID-19 vaccine, rAd26 and rAd5 have reported being open, nonrandomised phase 1/2 studies from Russia (Logunov et al. 2020).

The infection rate was so high, death toll became uncontrolled initially even in most developed countries like USA, Italy, Spain, France, UK, Germany, Russia etc (Paital et al. 2020). Till date, the number of total death cases in USA is 197,442 which is highest whereas the daily toll of fresh infection in $2^{\text {nd }}$ populated country India running around 0.1 million which is highest since last 40 days followed by Brazil. In this situation, prevention and management is the only option till proper vaccine comes out. As social distancing is highly important to control the rate of infection of COVID-19, the most of the countries have imposed partial or complete lock down measure at different levels (Statista 2020). In this long lockdown, there is a scope towards environment for self-sustaining.

\section{Method}

\subsection{Literature research}

The study included articles published in major online databases (PubMed, Google scholar and Scopus). The search strategy used a combination of controlled vocabulary and free 
text terms based on the following keywords: COVID-19 lockdown, effect of lockdown on environment, eco system, animal life. Research articles on atmospheric pollution, review articles on sustainable development in all respect have been searched for inclusion. All research fields were considered including news brief of reputed news agency and organization. Selected relevant articles separately screened the corresponding full text for final eligibility.

\subsection{Inclusion criteria and exclusion criteria}

All type of publications are considered with irrespective language. The studies included in this review focus on the effect of environment and ecosystem consequences of COVID19 found in this particular category of workers. Reports not related to COVID-19 are excluded. Updated reports of WHO and recent research articles on vaccine development are introduced in the literature review section.

\section{Result}

There were total 30 related research articles including letter to editor, feature, short communication, review articles related to the effect on environment parameter out of which three articles discussed little on effect of animal behaviour, though there were many evidence reported by news agency around the world, it needed to cover the all aspects.

\section{Discussion}

\subsection{Lockdown and atmospheric environment}

\subsubsection{Less $\mathrm{NO}_{2}$ and carbon emission improved air quality}

In the lockdown period due to restricted domestic activities, there are less industrial activities and less vehicle movement; the air pollution significantly decreases and environment have resumed some extend. Main sources of carbon emissions are the consumption of fossil fuels by industries, thermal power stations, air transports and vehicle traffic. Since industrial sectors, vehicular traffic was shut down in the lock down period; level of carbon concentration goes down. A study estimated the COVID-19 pandemic could reduce up to $7 \%$ global emission if the lock down extended till end of the year.

The important air pollutant, $\mathrm{NO}_{2}$ is usually emitted into the atmosphere from refining of petroleum and metals; welding, commercial manufacturing of nitric acid and N-based products including food processing industries. The combustion of fossil fuels like coal, gas and oil by factories, vehicles and even domestic purpose are responsible for $\mathrm{NO}_{2}$ pollution. As lockdown measures are implemented in European countries mainly Italy, Spain, France, Germany etc., variation in data owing to changing weather conditions. The satellite images, in Fig. 1, show $\mathrm{NO}_{2}$ concentrations from 13 March until 13 April 2020, compared to the March-April averaged concentrations from 2019. As the result of the strictly nationwise lockdown measures imposed across Europe, the populated cities in like Madrid, Rome, Milan are showing decreases by $45 \%$ concentration of $\mathrm{NO}_{2}$ in atmosphere, while Paris show remarkable drop by 54\% (ESA-Copernicus-European Space Agency 2020). 


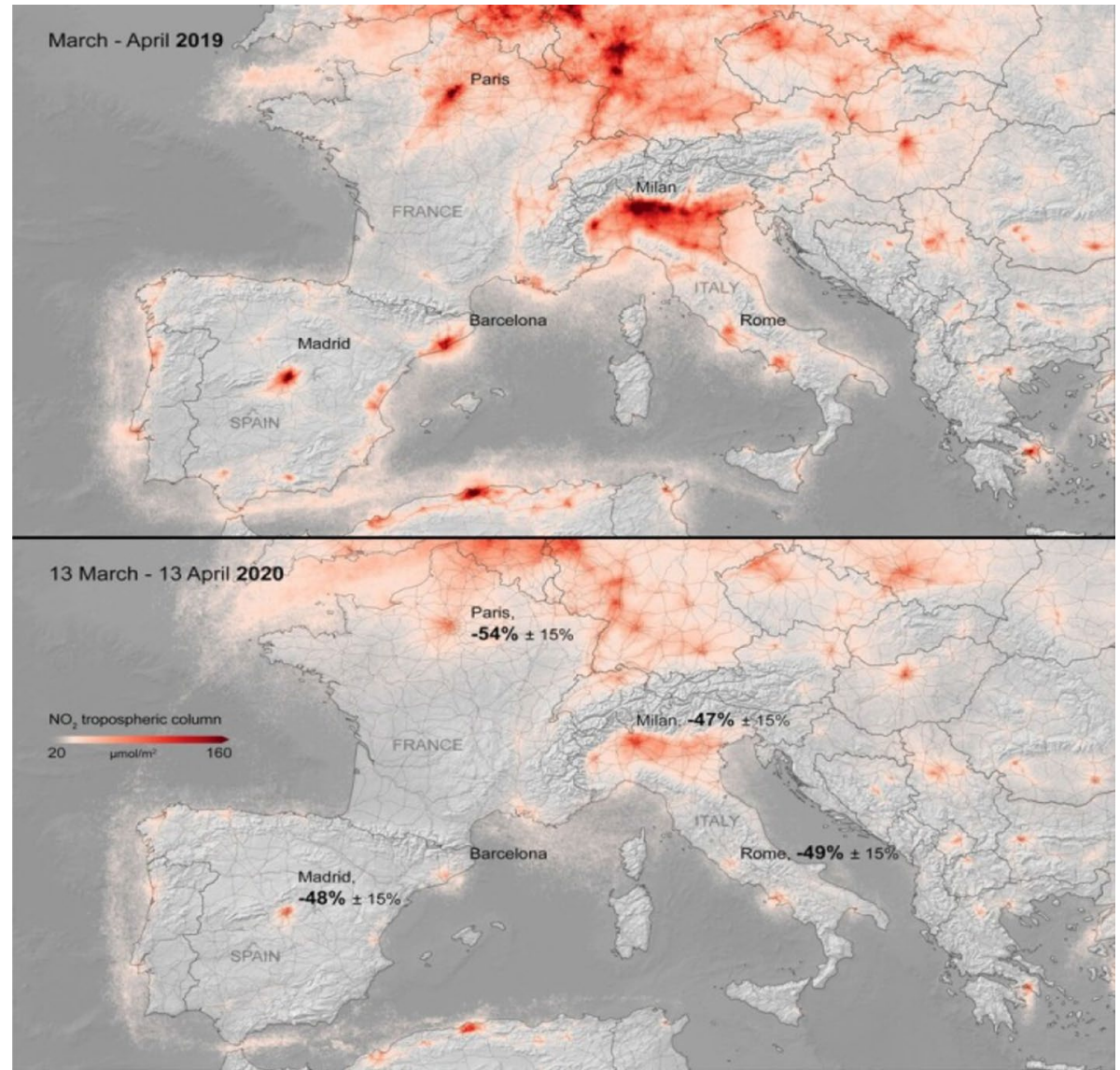

Fig. 1 The satellite image of Europe, showing average $\mathrm{NO}_{2}$ concentrations from 13th March until 13th April 2020, compared to that from 2019. (2020 Source: ESA—Copernicus-European Space Agency 2020, Access 26 May 2020)

Significantly reduction in the concentration of green house gases including $\mathrm{CO}_{2}$ and $\mathrm{NO}_{2}$ in the atmosphere is reported (Wang and Su 2020).

New satellite image in Fig. 2, captured by Copernicus Sentinel-5P satellite showing the significant reduction in the $\mathrm{NO}_{2}$ concentrations of India, where Mumbai and Delhi observed the drop of $\mathrm{NO}_{2}$ concentration by $40-50 \%$ due to nation-wise quarantine. Figure $3 \mathrm{a}$ identifies the major polluted location like thermal power stations in terms of higher $\mathrm{NO}_{2}$ concentration, measuring the concentrations $\geq 200 \mu \mathrm{mole} / \mathrm{m}^{2}$. A shadow of $\mathrm{NO}_{2}$ emissions from maritime traffic can be traced by the faint line over the Indian Ocean (Fig. 3b). International shipping track appears as straight marine lines owing to cargo ships following the same route (ESA — Copernicus_European Space Agency 2020).

\subsubsection{Less particulate matter improved the visibility}

The lockdown is an opportunity to environment for the improvement in air quality. The change in concentrations of seven air pollutants including particular matter $\left(\mathrm{PM}_{2.5}\right.$ and 

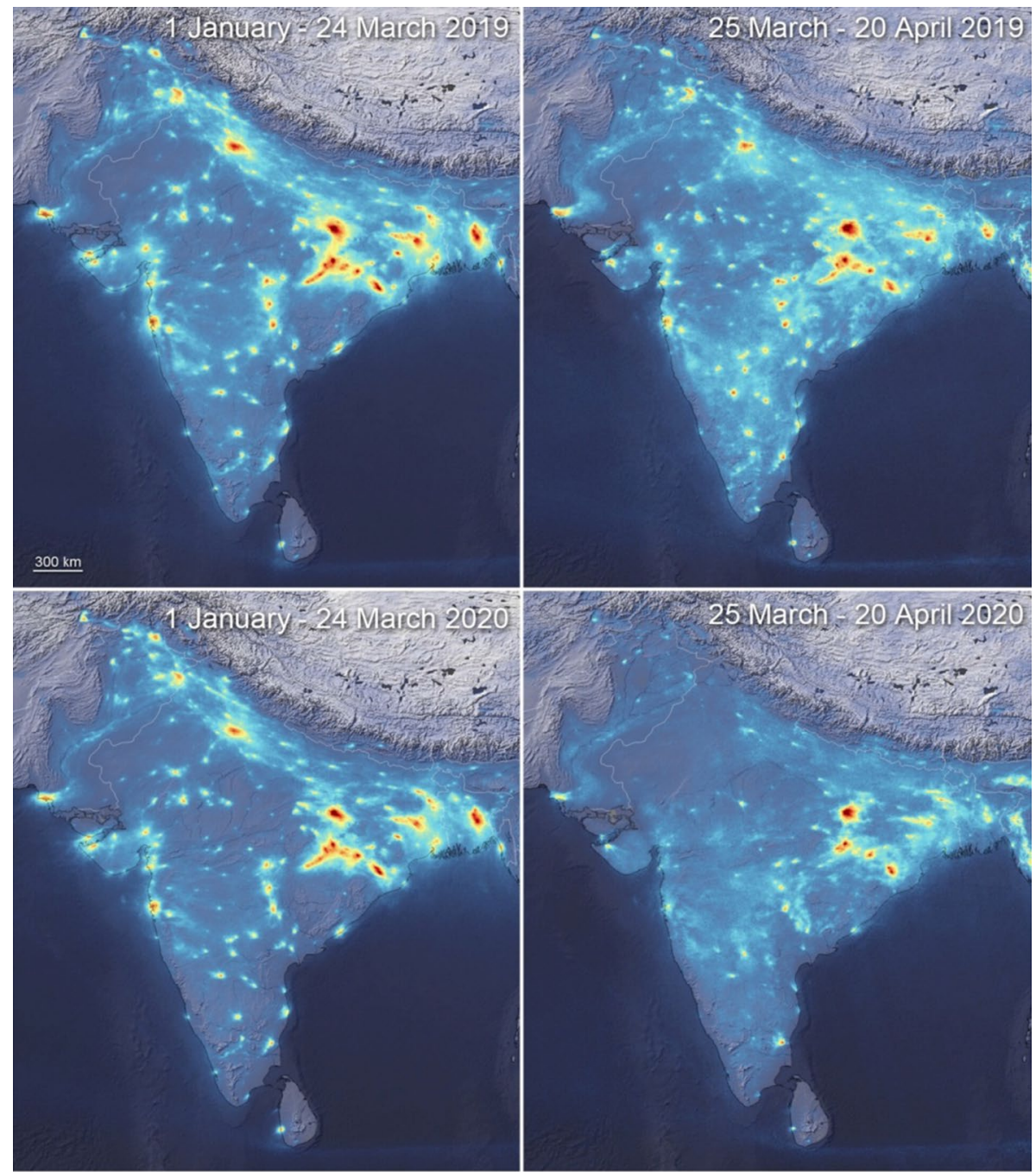

Sentinel-5P Nitrogen Dioxide tropospheric column

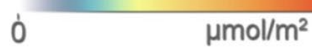

300

Fig. 2 New satellite maps, showing averaged $\mathrm{NO}_{2}$ concentrations over India. (2020 Source: ESA-Copernicus-European Space Agency 2020, Access 26 May 2020)

$\left.\mathrm{PM}_{10}\right)$, nitrogen oxides $\left(\mathrm{NO}_{\mathrm{x}}, \mathrm{NO}\right.$ and $\left.\mathrm{NO}_{2}\right)$, sulphur dioxide $\left(\mathrm{SO}_{2}\right)$, carbon monoxide (CO) of different populated urban areas in India have analysed and reported (Science the wire 2020). Among all the pollutant $\mathrm{PM}_{2.5}$ reduced significantly in the most of the regions. Around $43 \%$ decreased of $\mathrm{PM}_{2.5}$ indicates the decrease in carbon emission from limited traffic and $31 \%$ decreases of $\mathrm{PM}_{10}$ indicated the minimum re-sediment of dust particles caused by restricted works during lockdown period compared to the previous year (Sharma et al. 2020). USA and other countries are also experiencing the same trend from their 


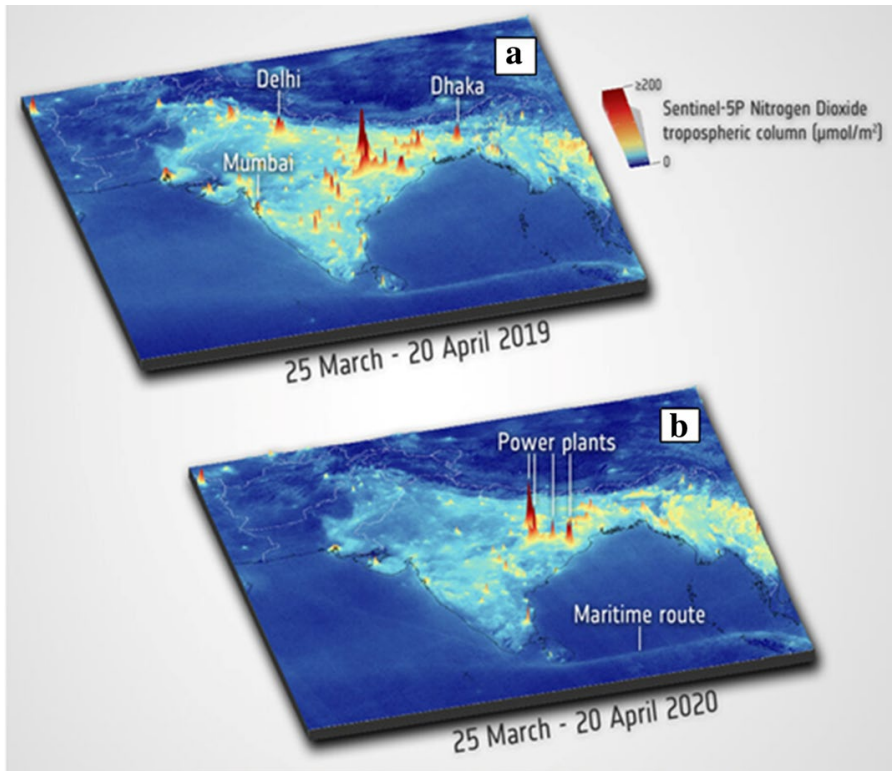

Fig. 3 a The major polluted locations indicating thermal power stations in terms of higher $\mathrm{NO}_{2}$ concentration. b Maritime traffic shows as a faded line in the Indian Ocean. (2020 Source: ESA-Copernicus-European Space Agency 2020, Access 26 May 2020)

normal level of $\left(\mathrm{PM}_{2.5}\right.$ and $\left.\mathrm{PM}_{10}\right)$ particulate matter shown in Table 1. As a result, the visibility at different cities becomes far better than the previous year (Saadat et al. 2020).

\subsubsection{Less industrial effluent discharge improved the water quality}

The clarity of the water has improved considerably and seaweed can be visualized in clear waters in Venice as a result of the restriction of motorboat traffic in the lockdown period in Italy. Due to pause in industrial effluent discharge into the canals of Venice, the schooling of fish in its water and swans floating around enjoying with unusual urban peace and quiet which was very unlike in normal city life (Mack 2020). The lockdown meant appears to clean water of India's holiest and polluted rivers, The Ganges (Times of India 2020a). The improvement in surface water quality in Vembanad Lake, India has reported and showing SPM concentration decreased by $15.9 \%$ on average compared with previous year (Yunus et al. 2020).

\subsubsection{Less river activities formed deserted bank}

During the lockdown period, all types of river transport means of boats, motor boats, steamer etc. are restricted. A certain portion of people in East Asia economically depends upon fishing in river. In the lockdown period such as river activities significantly stopped, resulting settlement in river are observed in river basin. Figure 4 shows a rare natural phenomenon of the deserted bank of the 'Sangam', the confluence of the rivers 'Ganga' and 'Yamuna', seen during lockdown in Prayagraj, Uttar Pradesh (India Today 2020). 


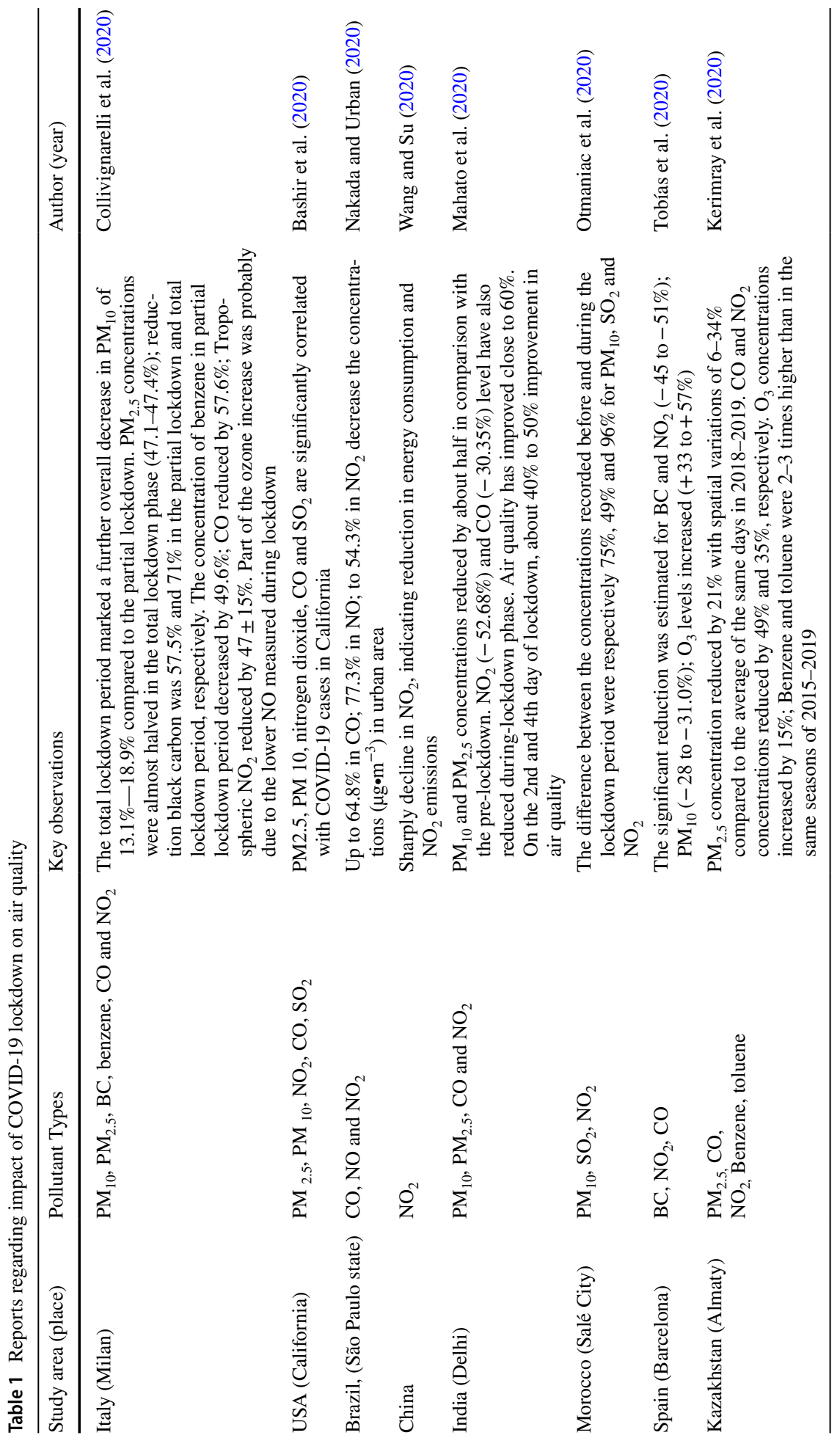


Fig. 4 The deserted banks of the confluence of the rivers Ganga and Yamuna, seen during lockdown. ( Source: India Today, 2020, Access 26 May 2020)

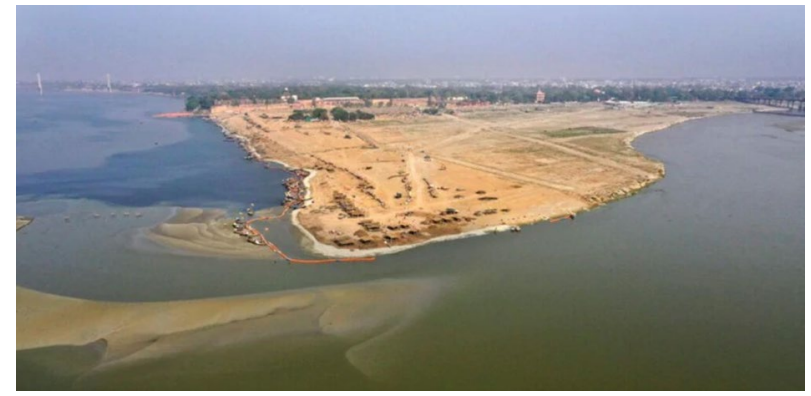

\subsubsection{Less human activities improved the noise quality}

The sound from air craft, industries, vehicles, local loudspeakers, crowed market places etc. are the cause of several mental and physical problems like dementia, deafness, headache, stroke even heart attack. Buzzing the vehicle horns is one of the biggest problems in city life, sometime it exceeds $100 \mathrm{db}$; the lockdown for COVID-19 has fall down the noise pollution. The reliable news agency, 'The times of India' reported the lower noise level $(\sim 30-40 \mathrm{db})$ in residential area and ( 50db) in the crowed metro station area (Times of India 2020b). Ocean Networks Canada found a significant drop in low-frequency sound associated with ships and fishing motor boat and the drop in underwater noise pollution that is the healthy message for whales and other water lives (The Guardian 2020a).

In this section, we found the degree of atmospheric pollution declined immediately due to restricted human activities in industry, transportation and domestic purpose. The concentration of major air-pollutant $\mathrm{NO}_{2}$ reduced upto 45 to $54 \%$ in European countries. It assumed reduction in carbon emission by $7 \%$ at end of this year. The pollution from oxides of nitrogen and carbon including their derivatives reduces the green house effect of atmosphere. The level of particulate matters like $\mathrm{PM}_{2.5}$ and $\mathrm{PM}_{10}$ significantly decrease $43 \%$ and $31 \%$, respectively, in the lower atmosphere of the different regions of globe. Suspended particulate matter dropped down up to $15.9 \%$ that indicates improvement in surface water quality.

The uniqueness of this article is to discuss on the development of a deserted banks at confluence of the rivers 'Ganga' and 'Yamuna' in India in river basin. Noise pollution remarkably dropped below $60 \mathrm{db}$ even in crowded cities. It also specially explained the effect noise in birds and butterfly life. From above observations, it may summarized that the atmospheric environment has resumed some extent in all respect by means of such global-wide lockdown aiming to control COVID-19 pandemic. The focus of this article is to assess the degree of devastation of environment, we doing in the process of normal global civilization.

\subsection{Lockdown and animal life}

\subsubsection{COVID-19 infection in Wildlife}

Not only the human being, animals are infected by the COVID-19 having symptoms with dry cough, loss of appetite. A tiger at New York's Bronx Zoo found confirm 
infected by Covid-19 and it supposed to have contracted the virus from a asymptomatic caretaker (Economic Times 2020a). An article in a nature research journal reported that the cats can be infected with COVID-19 and can transmit to other cats, but dogs are not susceptible to the infection. Harbin Veterinary Research Institute also reported that the chickens, pigs and ducks are not likely to infect the virus (Nature news 2020). Though it is unknown whether felines can transmit the virus to people, the pet owners have to not panic.

The animal health will likely be impacted by COVID-19 through the immediate consequences of lockdown. In the short term, some of the veterinary activities regarding preventative vaccination against pre-existing diseases would be suppressed during the lockdown (Gortázar and de la Fuente 2020). In addition with this, the indirect effects such as increased wildlife-livestock contacts, no population control or extended on-farm stays of stock will trigger the incidence of transmissible animal pre-diseases like African swine fever (ASF) (O'Neill et al. 2020). The long-term consequences of COVID-19 on animal health will be related to economic crisis on farmer livelihoods and veterinary service capacities.

\subsubsection{Effect on wildlife behaviour}

The COVID-19 lockdown offers a scope for experiment in animal behaviour. Unexpected reduction in human activity and sudden silence in locality surprised the animals and push to uncommon behaviour. For evidence, a puma walked along a street in Santiago, Chile; the herd of deer in Nara, Japan and raft of ducks crossing the road in Paris observed. (The Telegraph 2020; The guardian 2020b). Animals that normally hide in the shadows of our localities have suddenly come into the light, looking for food and roaming. A racoon found frolicking near residential area in broad daylight in Central Park, New York on 16 April 2020. Mountain goats roamed on the busy streets of Llandudno, Wales, UK on 31 March. The goats normally surf on the rocky Great Orme, but come down to the lonely streets with no people and tourists. Another such evidences found like a herd of fallow deer grazed on the lawns near housing estate in Harold Hill London on 4 April; peahens seen at MN Marg during lockdown in New Delhi; a leopard spotted on Hyderabad road during lock down shown in Fig. 5. (The Telegraph 2020; The guardian 2020b). The facts like the use of human dominated zones by wildlife are uncommon; let see what will change when lockdown removed. It may be seemed the 'unexpected vacation' for them during lockdown, when people are at home.

\subsubsection{Effect on aquatic life behaviour}

COVID-19 lockdown moves forward the healthy water environment and aquatic life. A rare sighting of Eagle rays watering at Dubai Marina while very few people were at port (CNN 2020). As beaches closed in lock down situation, turtles found nesting in peace at Florida (CNN 2020). Times of India reported on 25th April 2020, that after nearly three decades, a south Asian river dolphin which is known as 'Ganges Dolphin' was back at Kolkata, India (Times of India 2020c). All the evidences are somehow related to the instant change in ecosystem of the forestry and water. 

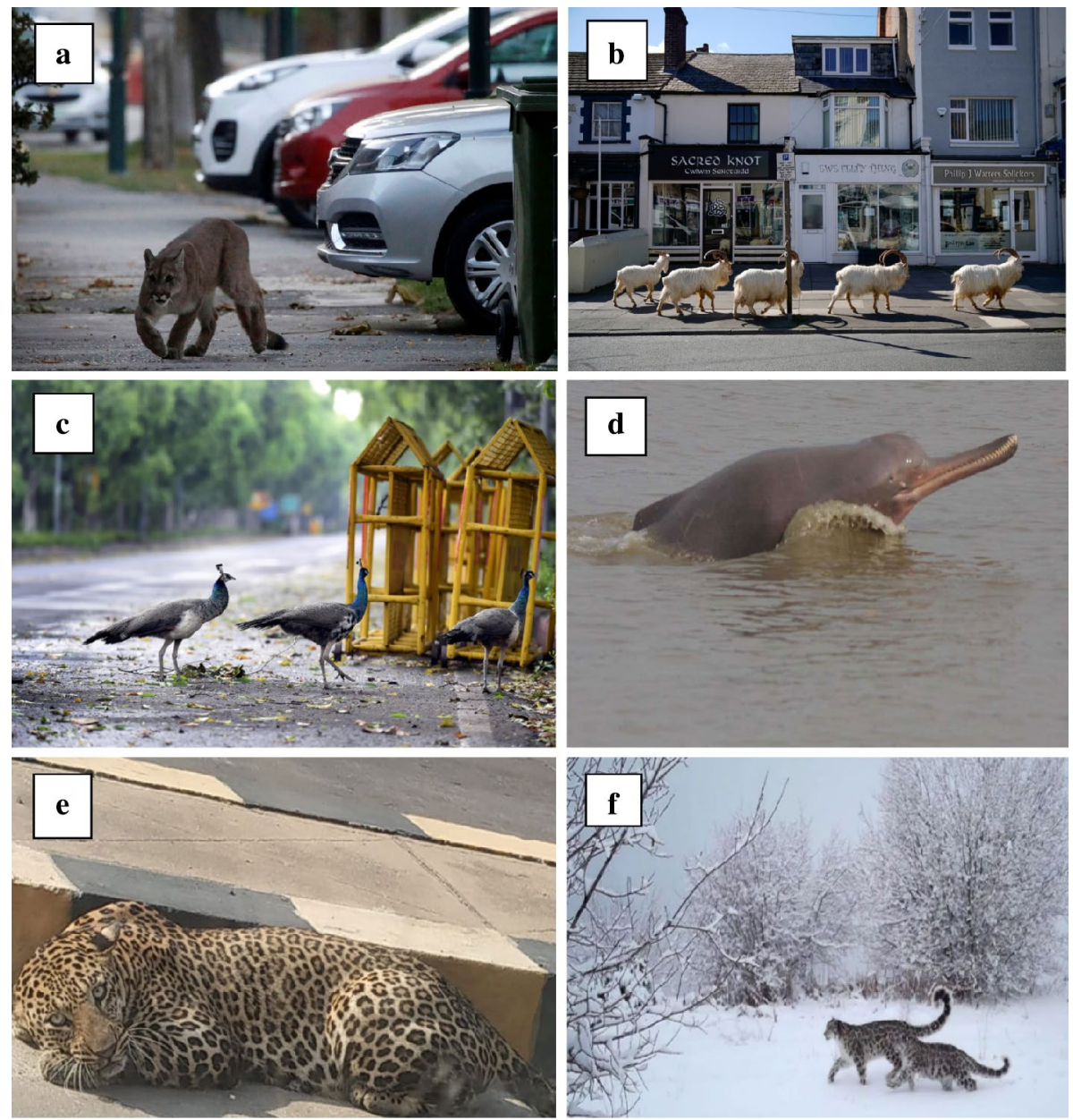

Fig. 5 The evidences of behavioural changes of animals and birds; a Puma walking at the street in Santiago, Chile. b Mountain goats roaming at the streets of Llandudno, Wales, UK; c Peahens observed at M N Marg, New Delhi, India; d Dolphins spotted at Kolkata, India; e Leopard lying on road at Hyderabad, India; f Snow leopards spotted near the Big Almaty Lake, Kazakhstan. a 2020a, b. Source: The Telegraph 2020, Access 26 May 2020, b and c Source: The guardian 2020a, b, Access 26 May 2020, d Source: Times of India 2020, Access 26 May 2020, e Source: NDTV 2020, Accessed 26 May 2020, f Source: The Astana Times 2020, Accessed 26 May 2020

\subsubsection{Effect on birds' life behaviour}

There are huge negative impacts of noise pollution on birds' life. So the silence lockdown appears to have peaceful living of birds. Typical changes in behaviour of partial migratory birds are observed and staying in sanctuaries a bit longer. The birds species like open bill stork, painted stork, grey heron, spoonbill, spot-billed pelican and ibis generally leave here by March. But in this year, they have extended their staying that may due to less human activity and less noise pollution in lockdown period (The Hindu 2020). The birds and butterflies have surged significantly across the country. Resident birds are breeding much 
more than before due to less human activity, no noise and air pollution (India New England 2020).

\subsubsection{Effect on pets behaviour}

Pets also have some routine activities. In the lockdown period, the restriction affects their normal behaviour pattern. Sometimes they become ferocious and behaved abnormal. Though the common pets like dogs, chickens, pigs and ducks are not likely to be infected; pet owners having no scope to move out them. The cats are suspected to carry and spread the virus, and special care need for such species (Nature news 2020).

\subsubsection{Food security of animals}

Generally local street dogs, cats, monkeys, crows and free birds depend upon the foods of tourist and domestic persons. During lockdown, they are in crisis of food, sometimes fighting with each other in the process. Afterward Govt. and few NGOs are arranging the 'natural restaurants' for animals. The roaming of the wild animals at residential area may be due to the shorted in the food. Such that, the deer in Nara Park, Japan are usually fed by visitors, but at lockdown period, that food dried up. It may be that they have left the park and taken to the streets of the city to look for food.

\subsection{Lockdown and ecosystem}

The worldwide animal market, where thousands of species are bought and sold every year, is a serious threat to biodiversity (DW 2020). As the COVID-19 outbreak was start from Hunan seafood market, China has temporarily ban on wildlife treading (Chakrabarty and Maity 2020). As it supposed transferable disease originated from animals, different countries also permanently ban wildlife tread; that will be good for wildlife health and restoring the sustainable eco-system.

An environmental NGO group, Ocean Asia surveyed in Hong Kong, found a good numbers of mask along with other disposal at high tied line of seashore (Saadat et al. 2020). If the biomedical garbage are not discarded according to the medical protocol it may lead infection even death of animals and water lives by mistakenly eat these as food (Hellewell et al. 2020) and ecosystem of both land and water may be affected. So restructuring of policies in regarding medical wastes management of COVID-19 needed immediately.

Handling of COVID-19 dead body is another new environmental issue. The number of death in COVID-19 till date is around 0.948 million; it increases by every hours. Dead bodys are needed to be mass buried rather than handed over to their family for ritual.

\subsection{Lockdown and human life style}

The secondary effect of COVID-19 lockdown must be the global socio-economic condition. It changes the life style of every level of nation irrespective of race, religion, politics and economic condition. Unfortunately affected COVID-19 patient or recovered persons feeling unusual behaviour from neighbours (Messner 2020). Sudden changes in life style like use masks, washing hand with soap, use of sanitizer, use of gloves are very unlikely. Daily routine observed to changes most of city-dwelling people. Most are engaged in online-based entertainment etc. Sometimes they are misguided by the myths and fake news waving round. Social 
relationship between teacher-student, doctor patient, house owners-tenant, boss-subordinates, factory owner-worker even have been affected some extent. Corporate sectors run on 'work from home' style; education system is going to be shifted to online basis; for children lockdown is nothing but imprisonment.

The unpredictable consequences of public health and misinformation about COVID-19 often impacts individuals' mental health including depression, anxiety, traumatic stress etc. The sadness, fear, anger, worry, annoyance, frustration, helplessness, loneliness and nervousness etc. are the common features of psychological problems suffering by major portion of people experienced during this pandemic situation. Economic fallout and joblessness triggered the mental health crisis that even lead to self-harm and suicidal behaviour (CNBC 2020; The Economic Times 2020b; Ahorsu et al. 2020; Banerjee 2020).

Most of the doctors and medical staff are engaged in COVID-19 treatment in emergency basis instead of other clinical service affected. In this circumstance, medical doctors, nurses and clinical pathologists nationwide moved in to provide medical treatment, assistances and relief. Citizens' voluntary codes of conduct, community consciousness, participated in volunteer services, financial donation in relief fund are noticed.

Most religious groups also refrained from large-scale gatherings by conducting online worship services and delaying Buddha's Day celebration. The "good landlord movement" that temporarily lowers rent by 20-30\% spreads across in Korea (Shaw et al. 2020).

\subsection{Role of citizen}

According to WHO, hygienic measure and social distancing would be the key role to cope the adverse situation of COVID-19. Consciousness, social responsibility, individual role and united effort may protect human being, animal being and environment. Restriction in social gathering, producing minimum hazards and modest noise offer green environment. Health issue of COVID-19 infection in animals and protection including the food chain of the street animals be caring. The unlike behaviour of animals is positive indication of self-sustaining ecology; we would be lucky to keep up it. People should be more concern about the environmental health even after the COVID-19 pandemic over.

The discussion deals the effect of sustained environment, resulting from long lockdown on the natural creatures including wild animal, aquatic lives, birds, pet animals and even human lifestyle. There are many evidence of peaceful movement of wild animals and aquatic lives at the human domain places. Significant behavioural changes of birds, butterfly, pets and street animals are discussed. The discussion on the correlation between atmospheric change with the behavioural changes of natural creature is the uniqueness of this study compared to others. The consequences of lockdown in human life style and its effect on ecosystem and role of citizen relating to COVID-19 lockdown also discussed. These observations indicate the interference of human activities on lives of natural creatures. The impact of human confinement in lockdown on sustainable atmospheric environment and its effect on lifestyle of natural creatures in their respective ecosystem discussed here identifies the scope of critical analysis on atmospheric environmental and life style of natural creatures in no man's land. 


\section{Conclusion}

The nation-wide lockdown is the only preventive measure to control community transmission of COVID-19. Obviously global economic growth declined due to lockdown measure; but there are certain positive impacts on atmospheric environment and sustainable ecosystem. Due to long time mass confinement, the major pollutants like oxides of nitrogen and carbon reduced significantly. The concentration of $\mathrm{NO}_{2}$ dropped down upto 45 to $54 \%$ in different populated countries in Europe, and reduced around 40-45\% identified at the thermal power location in India and Bangladesh compared to same time frame of previous years. The total carbon emission would be reduced by $7 \%$ at end of this year. In the lockdown period, the level of $\mathrm{NO}_{2}$ and carbon emission remarkably decreases in atmosphere due to restricted consumption of fossil fuel by industries, thermal power station and transportation. The intensities of particulate matters like $\mathrm{PM}_{2.5}$ and $\mathrm{PM}_{10}$ decreased by $43 \%$ and $31 \%$, respectively, at lower atmosphere and improved air qualities in different parts of world caused by less traffic and construction activities. SPM lowered down upto $15.9 \%$ causes the improvement in surface water quality. A very rare deserted bank observed to develop at the confluence of the rivers 'Ganga' and 'Yamuna' in India in river basin during lower river activity. Noise pollution remarkably dropped below $60 \mathrm{db}$ even in crowded cities. So it may be concluded that the atmospheric environment has resumed some extent in all respect by means of such globalwide lockdown aiming to control COVID-19 pandemic. The behavioural changes of wild animals, birds, butterfly, pets and street animals indicate the interference of human activities on lives of natural creatures. There is certain correlation between atmospheric changes with the behavioural changes of natural creature during lockdown period. The article focused on the impact of human confinement in lockdown on sustainable atmospheric environment and its effect on lifestyle of natural creatures in their respective ecosystem. It offers a scope to assess the degree of devastation of environment we do in the process of normal civilization. This article identified a scope of research and analysis on atmospheric environmental and life style of natural creatures in absence of human being.

Acknowledgements The author is thankful to Prof. Ajay Kumar Misra, Department of Chemistry, Vidyasagar University, West Bengal, India.

\section{References}

Ahorsu, D. K., Lin, C.-Y., Imani, V., Saffari, M., Griffiths, M. D., \& Pakpour, A. H. (2020). Fear of COVID19 scale: Development and initial validation. International Journal of Mental Health and Addiction. https://doi.org/10.1007/s11469-020-00270-8.

Agostini, M. L., Andres, E. L., \& Sims, A. C. (2018). Coronavirus Susceptibility to the Antiviral Remdesivir (GS-5734) Is mediated by the viral polymerase and the proof readingexoribonuclease. mBio, 9 , 221-218.

Andersen, K. G., Rambaut, A., Lipkin, W. I., Holmes, E. C., \& Garry, R. F. (2020). The proximal origin of SARS-CoV-2. Nature Medicine. https://doi.org/10.1038/s41591-020-0820-9.

Banerjee, D. (2020). The COVID-19 outbreak: Crucial role the psychiatrists can play. Asian Journal of Psychiatr, 50, 102014.

Bashir, M. F., Ben Jiang, M. A., Bilal, K. B., Bashir, M. (2020). Correlation between environmental pollution indicators and COVID-19 pandemic: A brief study in Californian context. Environmental Research, 187, Article 109652. 
Chakrabarty, I., \& Maity, P. (2020). COVID-19 outbreak: Migration, effects on society, global environment and prevention. Science of the Total Environment, 728, 138882.

CNBC (2020). https://www.cnbc.com/2020/04/15/imf-coronavirus-to-create-more-unemployment-inspain-than-italy.html. Accessed 26 May 2020.

CNN, (2020). https://edition.cnn.com/travel/article/marine-conservation-uae-spc-intl/index.html. Accessed 26 May 2020.

Collivignarelli, M. C., Abbà, A., Bertanza, G., Pedrazzani, R., Miino M. C. (2020). Lockdown for CoViD-2019 in Milan: What are the effects on air quality? Science of The Total Environment, 73225, Article 139280.

Corman, V. M., Landt, O., Kaiser, M., Molenkamp, R., Meijer, A., Chu, D. K., et al. (2020). Detection of 2019 novel coronavirus (2019-nCoV) by real-time RT-PCR. Euro Surveillance, 25, 2000045.

Dong, L., Hu, S., \& Gao, J. (2020). Discovering drugs to treat coronavirus disease 2019 (COVID-19). Drug Discoveries \& Therapeutics, 14(1), 58-60. https://doi.org/10.5582/ddt.2020.01012.

DW. (2020). https://www.dw.com/en/opinion-faith-covid-19-and-the-push-for-a-healthy-environment/a53270128 29.4.20. Accessed 26 May 2020.

Fehr, A. R., \& Perlman, S. (2015). Coronaviruses: An overview of their replication and pathogenesis. Methods in Molecular Biology, 1282, 1-23.

Folegatti, P. M., Ewer, K. J., Aley, P. K., Angus, B., Becker, S., Belij-Rammerstorfer, S., et al. (2020). Safety and immunogenicity of the ChAdOx $1 \mathrm{nCoV}-19$ vaccine against SARS-CoV-2: A preliminary report of a phase 1/2, single-blind, randomised controlled trial. The Lancet, 396(10249), 467-478.

ESA_Copernicus_European Space Agency (2020). https://www.esa.int/Applications/Observing_the_ Earth/Copernicus/Sentinel-5P/Air_pollution_drops_in_India_following_lockdown. Accessed 26 May 2020.

Gautret, P., Lagier, J. C., Parola, P., Hoang, V. T., Meddeb, L., Mailhe, M., et al. (2020). Hydroxychloroquine and azithromycin as a treatment of COVID-19: Results of an open-label non-randomized clinical trial. The International Journal of Antimicrobial Agents. https://doi.org/10.1016/j.ijant imicag.2020.105949.

Gortázar, C., \& de la Fuente, J. (2020). COVID-19 is likely to impact animal health. Preventive Veterinary Medicine, 180, 105030.

Guangdi, Li, \& Clercq, D. E. (2020). Therapeutic options for the 2019 novel coronavirus (2019-nCoV). Nature Reviews Drug Discovery, 19(3), 149-150.

Hellewell, J., Abbott, S., Gimma, A., Bosse, N. I., Jarvis, C. I., Russell, T. W., et al. (2020). Feasibility of controlling COVID-19 outbreaks by isolation of cases and contacts. The Lancet Global Health, 8(4), 488-496.

Huang, F., Li, Y., Lai-Han, L. E., Liua, X., Liu, K., Wang, Q., et al. (2020). A review of therapeutic agents and Chinese herbal medicines against SARS- COV-2 (COVID-19). Pharmacological Research, 158, 104929.

India New England. (2020). https://indianewengland.com/2020/04/india-sees-surge-in-the- populationof-birds-and-butterflies-amid-lockdown/. Accessed 26 May 2020.

India Today. (2020). https://gulfnews.com/photos/news/covid-19-in-india-lockdown-reveals-fresh-aircleaner-rivers-1.1587534887882. Accessed 26 May 2020.

Iswariya, G. T., Paital, B., Padma, P. R., \& Nirmaladevi, R. (2019). microRNAs: epigenetic players in cancer and aging. Frontiers in Bioscience (Scholar Edition), 11, 29-55.

Jiang, S., Hillyer, C., \& Du, L. (2020). Neutralizing antibodies against SARS-CoV-2 and other human coronaviruses. Trends Immunology, 41, 355e9.

Kaur, S. P., \& Gupta, V. (2020). (2020) COVID-19 Vaccine: A comprehensive status report. Virus Research, 288, 198114.

Kerimray, A., Baimatova, N., Ibragimova, O. P., Bukenov, B., Kenessov, B., Plotitsyn, P., et al. (2020). Assessing air quality changes in large cities during COVID-19 lockdowns: The impacts of trafficfree urban conditions in Almaty Kazakhstan. Science of the Total Environment, 730, 139179.

Kerr, C., Hughes, G., McKenna, L., \& Bergi, C. (2020). Prevalence of smell and taste dysfunction in a cohort of CoVID19 outpatients managed through remote consultation from a large urban teaching hospital in Dublin, Ireland. Infection Prevention in Practice, 2(3), 100076.

Knoops, K., Kikkert, M., Worm, S. H., Zevenhoven-Dobbe, J. C., Van der Meer, Y., Koster, A. J., et al. (2008). SARS-coronavirus replication is supported by a reticulovesicular network of modified endoplasmic reticulum. PLOS Biology, 6, e226.

Ko, W. C., Rolain, J. M., Lee, N. Y., Chen, P. L., \& Hsueh, P. R. (2020). Arguments in favour of remdesivir for treating SARS-CoV-2 infections. International Journal of Antimicrobial Agents. https:// doi.org/10.1016/j.ijantmicag.2020.105933. 
Lai, M. M. C., Perlman, S., \& Anderson, L. J. (2007). Coronaviridae. In D. M. Knipe \& P. M. Howley (Eds.), Fields virology (pp. 1305-1335). Philadelphia, PA: Lippincott Williams \& Wilkins.

Lan, J., Ge, J., Yu, S., Shan, H., Zhou, S., Fan, Q., et al. (2020). Structure of the SARS-CoV-2 spike receptor-binding domain bound to the ACE2 receptor. Nature, 581(7807), 215-220.

Liu, W., Morse, J. S., Lalonde, T., \& Xu, S. (2020). Learning from the past: possible urgent pre-vention and treatment options for severe acute respiratory infections caused by 2019- nCoV. ChemBioChem. https://doi.org/10.1002/cbic.202000047.

Logunov, D. Y., Dolzhikova, I. V., Zubkova, O. V., Tukhvatullin, A. I., Shcheblyakov, D. V., Dzharullaeva, A. S., et al. (2020). Safety and immunogenicity of an rAd26 and rAd5 vector-based heterologous prime-boost COVID-19 vaccine in two formulations: two open, non-randomised phase $1 / 2$ studies from Russia. The Lancet. https://doi.org/10.1016/S0140-6736(20)31866-3.

Loutfy, M. R., Blatt, L. M., Siminovitch, K. A., Ward, S., Wolff, B., Lho, H., et al. (2003). Interferon Alfacon-1 plus corticosteroids in severe acute respiratory syndrome: a preliminary study. Journal of the American Medical Association, 290(24), 3222-3228.

Lu, H., Stratton, C. W., \& Tang, Y. W. (2020). Outbreak of pneumonia of unknown etiology in Wuhan China: The mystery and the miracle. Journal of Medical Virology, 92(4), 401-402.

Lu, G., \& Liu, D. (2012). SARS-like virus in the Middle East: A truly bat-related coronavirus causing human diseases. Protein \& Cell, 3, 803-805.

Mack, E. (2020). Global coronavirus shutdowns let the environment breathe a bit easier. https://www. cnet.com/news/global-coronavirus-shutdowns-let-the-environmentbreathe-a-bit-easier. Accessed 26 May 2020.

Mackay, I. M., \& Arden, K. E. (2015). MERS coronavirus: diagnostics, epidemiology and trans- mission. Virology Journal, 12, 222.

Mahato, S., Pal, S., \& Ghosh, K. G. (2020). Effect of lockdown amid COVID-19 pandemic on air quality of the megacity Delhi, India. Science of The Total Environment, 73015 article 139086.

Messner, W. (2020). The institutional and cultural context of cross-national variation in COVID-19 outbreaks. Med Rxiv. https://doi.org/10.1101/2020.03.30.20047589.

Nature news. (2020). https://www.nature.com/articles/d41586-020-00984-8 Accessed 26 May 2020.

Nakada, L. Y. K., \& Urban, R. C. (2020). COVID-19 pandemic: Impacts on the air quality during the partial lockdown in São Paulo state, Brazil. Science of The Total Environment, 73015, Article 139087.

NDTV. (2020). https://www.ndtv.com/hyderabad-news/leopard-spotted-lying-on-hyderabad-road-amidcovid-19-lockdown-2228791. Accessed 26 May 2020.

Ny Times. (2020). https://www.nytimes.com/2020/04/03/upshot/coronavirus-jobless-rate-great-depre ssion.html. Accessed 26 May 2020.

O’Neill, X., White, A., Ruiz-Fons, F., \& Gortázar, C. (2020). Modelling the transmission and persistence of African swine fever in wild boar in contrasting European scenarios. Scientific Reports, 10, 5895.

Otmaniac, A., Benchrif, A., Tahri, M., Bounakhla, M., El Chakir, M., Bouch, M. E., et al. (2020). Impact of Covid-19 lockdown on PM10, SO2 and NO2 concentrations in Salé City (Morocco). Science of The Total Environment, 735, 139541.

Paital, B., Das, K., \& Parida, S. K. (2020). Inter nation social lockdown versus medical care against COVID-19, a mild environmental insight with special reference to India. Science of the Total Environment, $728,138914$.

Pang, J., Wang, M. X., Ang, I. Y. H., Tan, S. H. X., Lewis, R. F., Chen, J. I., et al. (2020). Potential rapid diagnostics, vaccine and therapeutics for 2019 novel coronavirus (2019- nCoV): A systematic review. Journal of Clinical Medicine, 9, 623.

Saadat, S., Rawtani, D., \& Hussain, C. M. (2020). Environmental perspective of COVID-19. Science of the Total Environment, 728, 138870.

Sharma, S., Zhang, M., Anshika, G. J., Zhan, H., \& Kota, S. H. (2020). Effect of restricted emissions during COVID-19 on air quality in India. Science of the Total Environment, 728, 138878.

Shaw, R., Kim, Y., \& Hua, J. (2020). Governance, technology and citizen behavior in pandemic: Lessons from COVID-19 in East Asia. Progress in Cardiovascular Diseases, 6, 100090.

Science News. (2020). COVID-19 coronavirus epidemic has a natural origin. https://www.sciencedai ly.com/releases/2020/03/200317175442.htm. Accessed 26 May 2020.

Science the wire. (2020). https://science.thewire.in/environment/lockdown-air-pollution-north-india -pm25-pm10-nox-ozone/. Accessed 26 May 2020.

Sheahan, T. P., Sims, A. C., \& Leist, S. R. (2020). Comparative therapeutic efficacy of remdesivir and combination lopinavir, ritonavir, and interferon beta against MERS-CoV. Nature Communication, 11, Article No. 222. 
Smith, T., Bushek, J., \& Prosser, T. (2020). COVID-19 drug therapy-potential options, clinical drug information Clinical solutions, https://www.elsevier.com/_data/assets/pdf_file/0007/988648/COVID -19-Drug-Therapy_Mar-2020.pdf.

Statista. (2020). https://www.statista.com/chart/21240/enforced-covid-19-lockdowns-by-people-affectedper-country/ Accessed 26 May 2020.

The Astana Times. (2020). https://astanatimes.com/2020/05/wildlife-reclaims-almaty-lake-thanks-to-lockd own-measures-video/. Accessed 26 May 2020.

The Economic Times. (2020a). https://economictimes.indiatimes.com/magazines/panache/in-a-first-bronx -zoo-tiger-nadia-tests-positive-for-covid-19-develops-dry-cough-loss-ofappetite/articleshow/75001 865.cms? from=mdr. Accessed 26 May 2020.

The Economic Times. (2020b). https://economictimes.indiatimes.com/jobs/lockdown-would-have-deepe r-impact-52-ceos-foresee-job-losses-cii-snap-poll/articleshow/74992585.cms. Accessed 26 May 2020.

The Guardian. (2020a). https://www.theguardian.com/environment/2020/apr/27/silence-is-golden-for-whale s-as-lockdown-reduces-ocean-noise-coronavirus. Accessed 26 May 2020.

The Guardian. (2020b). https://www.theguardian.com/world/gallery/2020/apr/22/animals-roaming-streetscoronavirus-lockdown-photos. Accessed 26 May 2020.

The Hindu. (2020). https://www.thehindu.com/news/national/tamil-nadu/pandemic-induced-lockdowngives-migratory-birds-and-animals-a-reason-to-cheer/article31458071.ece. Accessed 26 May 2020.

The Telegraph. (2020). https://www.telegraph.co.uk/news/2020/04/12/scientists-using-coronavirus-lockd own-understand-wildlife-behaves/. Accessed 26 May 2020.

Times of India. (2020a). https://timesofindia.indiatimes.com/india/cleaner-ganga-cpcb-validates-impro vement-in-water-quality-sees-bigger-change-in-river-stretch-in-up/articleshow/75424439.cms. Accessed 26 May 2020.

Times of India. (2020b). https://timesofindia.indiatimes.com/india/covid-19-noise-pollution-falls-as-lockd own-rings-in-sound-of-silence/articleshow/75309318.cms. Accessed 26 May 2020.

Times of India. (2020c). https://timesofindia.indiatimes.com/travel/things-to-do/lockdown-effect-gangeticdolphins-spotted-at-kolkata-ghats-after-30-years/as75375783.cms. Accessed 26 May 2020.

Tobías, A., Carnerero, C., Reche, C., Massagué, J., Via, M., Minguillón, M. C., et al. (2020). Changes in air quality during the lockdown in Barcelona (Spain) one month into the SARS-CoV-2 epidemic. Science of The Total Environment, 726, 138540.

Wang, Q., \& Su, M. (2020). A preliminary assessment of the impact of COVID-19 on environment - A case study of China. Science of The Total Environment, 7281, Article 138915.

Xu, Z., Peng, C., \& Shi, Y. (2020). Nelfinavir was predicted to be a potential inhibitor of 2019-nCov main protease by an integrative approach combining homology modelling, molecular docking and binding free energy calculation. bioRxiv. https://doi.org/10.1101/2020.01.27.921627.

Yu, P., Hu, B., Shi, Z. L., \& Cui, J. (2019). Geographical structure of bat SARS-related coronaviruses. Infection, Genetics and Evolution, 69, 224-229.

Yunus, A. P., Masago, Y., \& Hijioka Y. (2020). COVID-19 and surface water quality: Improved lake water quality during the lockdown. Science of The Total Environment, 73120, Article 139012.

Zhou, F., Yu, T., Du, R., Fan, G., Liu, Y., Liu, Z., et al. (2020). Clinical course and risk factors for mortality of adult inpatients with COVID-19 in Wuhan, China: A retrospective cohort study. Lancet, 395(10229), 1054-1062.

Publisher's Note Springer Nature remains neutral with regard to jurisdictional claims in published maps and institutional affiliations.

\section{Affiliations}

\section{Harekrishna Bar ${ }^{1}$}

1 Department of Chemistry, Sabang Sajanikanta Mahavidyalaya, Lutunia, Paschim Medinipur, West Bengal 721166, India 